Dr. Groves chose both subjects and lecturers judiciously; and in editing the book he has managed to avoid many of the perils of multiple authorship, though some overlapping among the contributions inevitably remains. The book would form a sound basis for an academic postgraduate course on space dynamics: it is, however, too advanced for an undergraduate course, and some of the contributions are of greater academic than practical interest. The book is well printod and the layout is pleasing.

D. G. King-HeLe

\section{MATERIALS AT HIGH TEMPERATURES}

\section{Thermal Stress}

Edited by Dr. P. P. Benham and Dr. Russell Hoyle. Pp. $x+382$. (London: Sir Isaac Pitman and Sons, Ltd., 1964.) $90 s$. net.

Plenum Press Handbooks of High Temperature Materials No. 1. Materials Index

By Peter T. B. Shaffer. Pp. xx +740.17 .50 dollars.

No. 2. Properties Index

By G. V. Samsonov. Translated from the Russian. Pp. xii +418 . 22.50 dollars.

No. 3. Thermal Radiative Properties

By W. D. Wood, H. W. Deem and C. F. Iucks. Pp. 470. 17.50 dollars. (New York: Plenum Press, 1964.)

THERMAL Stress is a symposium based on a con1 ference held at the Imperial College of Science and Technology, London, in 1962, on the effects of temperature on the stresses within a body and on the properties of the component materials. It is divided into three parts, the first giving a résumé of the theoretical aspects of thermal stress, the second concerning thermal cycling and creep but also including a chapter on materials at high temperature, and the third detailing some industrial examples of thermal stress problems and their solution.

Like most pablished symposia, the book can be criticized for a lack of balance and completeness in dealing with its subject. The treatment of the high-temperature properties of materials, for example, is eursory, occupying only two out of twenty chapters, and would probably have been better omitted altogether. Regarded as a collection of papers, however, the book performs its function of presenting the thinking and results of those active in the field.

The Plenum Press Handbooks of High Temperature Materials provide, in three volumes, a wealth of data on those metals and ceramics that are used or usable at elevated temperatures. Volume 1 lists more than five hundred different ceramic materials such as carbides, borides, nitrides, sulphides, phosphides, silicides, and oxides, giving for each such structural, chemical, mechanical, thermal and physical data as could be culled from the sources consulted, theso being mainly U.S. Government reports. The data available about a given substance vary enormously and the reader may be froquently dis. appointed in not finding the information for which he seeks. The book does not claim, howevor, to be exhaustive, and the author, Dr. P. T. B. Shaffer, is to be complimented on providing a good start to the classification of hightemperature materials and their properties.

Volume 2 in the series is the translation of a Russian work by Prof. G. V. Samsonov in which data on refractory materials are classified according to properties rather than materials. It has a brief but useful introduction followed by data on structure, composition, density and thermal stability. Chapter 2 deals with thermal properties of all kinds, and the succeeding chapters cover in turn the electrical, optical, mechanical, chemical and refractory characteristics of these materials. Oxides are not covered in this book as they have been dealt with elsewhere. A final set of tables gives examples of the application of refractory compounds. This work is more exhaustive than Volume I with more than 1,300 references compared with less than 500 in the latter, but the two volumes are clearly complementary and together provide an indispensable source of collected data.

Volume 3 deals with the thermal radiative properties of high-temperature materials and contains data on titanium and its alloys, stainless steel, iron, nickel and cobalt and their alloys, chromium, columbium, molybdenum, tantalum and tungsten with their alloys, coated materials of many kinds, ceramics and graphites. For each material the data provided include a graph of emittance (spectral or total) against temperature (given unfortunately in degrees Fahrenheit) together with information on the methods and conditions of measurement and, of course, the reference. In many cases graphs of normal spectral emittance against wave-length at some reference temperatures are also supplied. There are introductory chapters on "Fundamentals and Definitions" and on "Methods of Measurement", the latter being a brief survey backed up by thirty references to the literature.

E. H. Andrews

\section{THE WORLD OF FISH}

\section{A Draught of Fishes}

By Dr. F. D. Ommanney. Pp. $254+23$ photographs. (London: Longmans, Green and Co., Ltd., 1965.) $36 s$. net.

COME twenty-three thousand species of fish inhabit S the waters of the world, more than those of all tho other vertebrates put together. Their habitat covers more than 70 per cent of the surface of the globe, and ranges from the sunshine and surf of the shore to the black death-like calm of the abyss. The fishes-using the word in its widest vernacular sense-are the oldest class among the living vertebrates, and have had many million years more than the other classes to evolve in adaptation to their infinitely varied environment; though time has apparently stood still for many of them since the Carboniferous, natural selection must yet be acting on the combinations and permutations in the gene pool of others. This great host, not only of species but also of individuals, provides a subject well suited to such an accomplished writer as Dr. Ommanney, who has spent many years in research on improving the yield of com. mercial fisheries in many parts of the world.

The book opens with a chapter sketching in the oceanographic background of the fish's world and of the fisheries that exploit its wealth. The various forms of fishing gear and their methods of use are then described, from the latest European $V \cdot D$ trawl, and the ships equipped with radar and fish-finding echo-sounders that use it, to the simple traps and fish-weirs so commonly used on tropica! coasts - not that simple "fixed engines" are extinct in Europe, for the wicker putchers still used in the Severn Estuary can be little different from the fish traps no doubt fished there when Julius Caesar first landed, or perhaps in neolithic times or even earlier. Dr. Ommanney intersperses his chapters on such subjects as shoaling, the colours of fishes, the abyss and the inshore waters, fresh waters, and the plankton feeding fishes, with others describing the different researches on specific fisheries, and the exploratory voyages undertakon in their prosecution, with which he has been associated. The last are among the best in the book, for his vivid style conveys the essential flavour of life in a trawler on the northern grounds off Iceland and Bear Island or with the tunny men of Brittany in the Bay of Biscay. 'The fisherman's world is 